\title{
ANALISIS EFEKTIVITAS DAN EFISIENSI PENGELOLAAN KEUANGAN DAERAH DI KOTA PALEMBANG
}

Oleh :

\author{
Anton Trianto* \\ Email: katon_at@yahoo.com \\ *Dosen Politeknik Darusalam Palembang
}

\begin{abstract}
Abstrak
Penelitian ini bertujuan untuk menganalisis sejauh mana tingkat efektivitas dan efisiensi keuangan daerah Kota Palembang. Data yang digunakan adalah data sekunder yaitu data APBD Kota Palembang periode anggaran 2003-2013. Untuk menghitung tingkat efektivitas dan efisiensi keuangan daerah Kota Palembang teknik analisis yang digunakan adalah dengan menghitung Rasio Efektivitas dan Rasio Efisiensi Keuangan Daerah. Hasil yang didapat menunjukkan bahwa Secara keseluruhan, rata-rata nilai rasio efektivitas keuangan daerah Kota Palembang periode tahun 2003-2013 mencapai tingkat yang efektif. Hal ini berarti pemerintah daerah Kota Palembang telah berhasil dalam merealisasikan Pendapatan Asli Daerah (PAD) dari target yang diperkirakan sebelumnya sehingga potensi PAD yang ada dapat dimaksimalkan oleh pemerintah daerah untuk menunjang pembangunan di Kota Palembang. Sementara itu, tingkat efisiensi keuangan daerah Kota Palembang selama periode 2003-2013 rata-rata berada pada tingkat kurang efisien dan tidak efisien. Hal ini berarti porsi penggunaan input (belanja) telah lebih dari 90 persen dibandingkan jumlah output (pendapatan). Dalam terminologi ekonomi dan keuangan hal ini merupakan kondisi yang tidak efisien bahkan pada periode tahun 2009, 2009 dan 2013 rasio efisiensi telah melebihi dari angka 100 persen yang menandakan belanja daerah telah melebihi anggaran yang tersedia sehingga pengeluaran belanja tersebut dibiayai dengan pinjaman/hutang.
\end{abstract}

Kata kunci: efektivitas, efisiensi, keuangan daerah

\section{PENDAHULUAN}

Pengelolaan anggaran pemerintah di masa sekarang mengacu pada sistem Penganggaran Berbasis Kinerja (PBK). Menurut Departemen Keuangan (2009: 11-20), ciri utama PBK adalah anggaran yang disusun dengan memperhatikan keterkaitan antara pendanaan (input), dan hasil yang diharapkan (outcomes), sehingga dapat memberikan informasi tentang efektivitas dan efisiensi kegiatan.

Sumengge (2013: 75) mengatakan bahwa anggaran pemerintah terkait dengan proses penentuan jumlah alokasi dana untuk tiap-tiap program dan aktivitas dalam satuan moneter yang menggunakan dana milik masyarakat. Anggaran publik merupakan alat perencanaan sekaligus alat pengendalian. Anggaran sebagai alat perencanaan mengindikasikan target yang harus dicapai oleh pemerintah, sedangkan anggaran sebagai alat pengendalian mengindikasikan 
alokasi sumber dana publik yang disetujui legislatif untuk dibelanjakan. Melalui data rekening belanja yang terdapat dalam anggaran belanja lembaga/organisasi pemerintah, akan dilihat apakah anggaran yang telah dibuat dapat berperan sebagai pengendali terhadap pelaksanaan kegiatan pemerintah.

Menurut Halim (2007: 234-241), pengukuran efektivitas dan efisiensi keuangan daerah dapat dilakukan dengan menghitung Rasio Efektivitas dan Rasio Efisiensi Keuangan Daerah. Rasio Efektivitas merupakan kemampuan pemerintahan daerah dalam merealisasikan PAD yang telah direncanakan dibandingkan dengan target yang ditetapkan berdasarkan potensi riil daerah. Sementara Rasio Efisiensi adalah rasio yang menggambarkan perbandingan realisasi pengeluaran (belanja) dengan realisasi penerimaan daerah.

Kota Palembang merupakan salah satu daerah yang memiliki banyak potensi daerah yang mampu di-optimalkan sebagai sumber penerimaan daerah. Sebagai ibu kota dan pusat pertumbuhan bagi Provinsi Sumatera Selatan, keberhasilan pembangunan di Kota Palembang akan membawa dampak positif bagi pertumbuhan daerah lainnya. Oleh karena itu, efektivitas dan efisiensi pengelolaan keuangan daerah memiliki peran yang penting dalam menunjang keberhasilan pembangunan dan kemudian bermuara pada peningkatan pertumbuhan ekonomi Kota Palembang serta pertumbuhan daerah-daerah lain di sekitarnya.

Pemilihan Kota Palembang sebagai objek penelitian didasarkan pada segi pengelolaan keuangan daerah. Pada tahun 2014 Kota Palembang telah memperoleh penghargaan 'Wajar Tanpa Pengecualian' (WTP) untuk penyajian dan pelaporan keuangan pemerintah Penghargaan tersebut diperoleh Kota Palembang berturut-turut sejak tahun 2010 yang menunjukkan bahwa pengelolaan keuangan Kota Palembang telah cukup baik selama ini. Hal tersebut menarik untuk dikaji lebih dalam tingkat efektivitas dan efisisensi pengelolaan keuangan daerah di Kota Palembang.

\section{TINJAUAN PUSTAKA}

\section{Sistem Pengelolaan Keuangan Daerah}

Salah satu unsur yang paling penting dalam penyelenggaraan pemerintah dan pembangunan di daerah adalah sistem pengelolaan keuangan daerah. Hal ini penting dan mendasar untuk memperbaiki berbagai kelemahan dan kekurangan yang ada serta upaya untuk mengakomodasi berbagai tuntutan dan aspirasi yang berkembang di masyarakat. Peraturan Pemerintah Republik Indonesia Nomor 105 tahun 2000 tentang pengelolaan dan pertanggungjawaban keuangan daerah menyebutkan, bahwa yang dimaksud dengan keuangan daerah adalah semua hak dan kewajiban daerah dalam rangka penyelenggaraan pemerintah daerah yang akan dinilai dengan uang termasuk di dalamnya segala bentuk kekayaan daerah tersebut, dalam kerangka Anggaran Pendapatan dan Belanja Daerah (APBD). Pasal 4 dan 5 menyebutkan, bahwa pengelolaan keuangan daerah dilakukan secara tertib, taat pada peraturan perundang-undangan yang berlaku, efisien, efektif, transparan, dan bertanggungjawab dengan memperhatikan azas keadilan dan 
kepatutan sehingga anggaran pendapatan dan belanja daerah merupakan dasar pengelolaan keuangan daerah dalam tahun anggaran tertentu.

Devas, et al (1989: 56) mengemukakan, bahwa pengelolaan keuangan daerah berarti mengurus dan mengatur keuangan daerah dengan prinsip pengelolaan keuangan sebagai berikut:

1. Tanggung jawab (Accountability). Pemerintah daerah harus mempertanggungjawabkan tugas keuangannya kepada lembaga atau orang yang berkepentingan yang sah. Lembaga atau orang itu adalah pemerintah pusat, DPRD, kepala daerah, dan masyarakat umum.

2. Memenuhi kewajiban keuangan. Keuangan daerah harus ditata sedemikian rupa, sehingga mampu melunasi semua ikatan keuangan, jangka pendek dan jangka panjang (termasuk pinjaman jangka panjang).

3. Kejujuran. Urusan keuangan harus diserahkan pada pegawai yang jujur, dan kesempatan untuk berbuat curang diperkecil.

4. Hasil guna (effectiveness) dan daya guna (efficiency). Tata cara mengurus keuangan daerah harus sedemikian rupa, sehingga memungkinkan program dapat direncanakan dan dilaksanakan untuk mencapai tujuan pemerintah daerah dengan biaya serendah-rendahnya dan dalam waktu secepat-cepatnya.

5. Pengendalian. Aparat pengelola keuangan pemerintah daerah, DPRD, aparat pengawas harus melakukan pengendalian agar semua tujuan tersebut di atas tercapai.

Mardiasmo (1999: 11) mengemukakan, bahwa salah satu aspek dari pemerintah daerah yang harus diatur secara hati-hati adalah masalah pengelolaan keuangan daerah dan anggaran daerah. Anggaran daerah atau APBD merupakan instrumen kebijakan yang utama bagi pemerintah daerah. Sebagai instrumen kebijakan, anggaran daerah menduduki posisi sentral dalam upaya pengembangan kapabilitas dan efektivitas pemerintah daerah.

\section{Anggaran Pendapatan dan Belanja Daerah (APBD)}

APBD adalah rencana keuangan tahunan pemerintahan daerah yang dibahas dan disetujui bersama oleh pemerintah daerah dan DPRD, dan ditetapkan dengan peraturan daerah (Permendagri No. 13 Tahun 2006, 2006:8). APBD merupakan dokumen yang mencerminkan kondisi keuangan pemerintah daerah yang di dalamnya tercantum informasi mengenai pendapatan, belanja, dan pembiayaan (Yuwono, 2005: 68).

Prinsip penyusunan APBD menurut Menteri Negara Otonomi Daerah RI dan PAU-SE UGM (2000: 5-8) sebagai berikut:

\section{Keadilan Anggaran}

Keadilan anggaran merupakan salah satu misi utama yang diemban pemerintah daerah dalam melakukan berbagai kebijakan, khususnya yang berkaitan dengan pengelolaan anggaran daerah. Pelayanan umum akan meningkatkan kesempatan kerja yang akan semakin bertambah, apabila fungsi alokasi belanja maupun mekanisme perpajakan serta retribusi yang lebih adil dan 
trasnparan. Hal tersebut mengharuskan pemerintah daerah untuk me-rasionalkan pengeluaran atau belanja secara adil untuk dapat dinikmati hasilnya secara proporsional oleh para wajib pajak, retribusi maupun masyarakat luar. Penetapan besaran pajak daerah dan retribusi daerah harus mampu menggambarkan nilainilai rasional yang transparan dalam menentukan tingkat layanan bagi masyarakat daerah.

\section{Efisiensi dan Efektivitas Anggaran}

Hal yang perlu diperhatikan dalam prinsip ini adalah bagaimana memanfaatkan uang sebaik mungkin agar dapat menghasilkan perbaikan pelayanan kesejahteraan yang maksimal guna kepentingan masyarakat. Secara umum, kelemahan yang sangat menonjol dari anggaran selama ini adalah keterbatasan daerah untuk mengembangkan instrumen teknis perencanaan anggaran yang berorientasi pada kinerja, bukan pendekatan incremental yang sangat lemah landasan pertimbangannya. Oleh karenanya, dalam penyusunan anggaran harus memperhatikan tingkat efisiensi alokasi dan efektivitas kegiatan dalam pencapaian tujuan dan sasaran yang jelas. Berkenaan dengan itu, maka penetapan standar kinerja proyek dan kegiatan serta harga satuannya, akan merupakan faktor penentu dalam meningkatkan efisiensi dan efektivitas angaran.

\section{Anggaran Berimbang dan Defisit}

Pada hakekatnya penerapan prinsip anggaran berimbang adalah untuk menghindari terjadinya hutang pengeluaran, akibat rencana pengeluaran yang melampaui kapasitas penerimaannya. Apabila penerimaan yang telah ditetapkan dalam APBD tidak mampu membiayai keseluruhan pengeluaran, maka dapat dipenuhi melalui pinjaman daerah yang dilaksanakan secara taktis dan strategis sesuai dengan prinsip defisit anggaran. Penetapan prinsip ini agar alokasi belanja yang dianggarkan sesuai dengan kemampuan penerimaan daerah yang realistis, baik berasal dari Pendapatan Asli Daerah (PAD), dana perimbangan keuangan maupun pinjaman daerah. Di sisi lain, kelebihan target penerimaan tidak harus selalu dibelanjakan, tetapi dicantumkan dalam perubahan anggaran dalam pasal cadangan atau pengeluaran tidak tersangka, sepanjang tidak ada rencana kegiatan mendesak yang harus segera dilaksanakan.

\section{Disiplin Anggaran}

Struktur anggaran harus disusun dan dilaksanakan secara konsisten. APBD adalah rencana pendapatan dan pembiayaan penyelenggaraan pemerintahan dan pembangunan daerah untuk 1 (satu) tahun anggaran tertentu. Bila terdapat kegiatan baru yang harus dilaksanakan dan belum tersedia kredit anggarannya , maka perubahan APBD dapat disegerakan dan dipercepat dengan memanfaatkan pasal pengeluaran tak tersangka, bila masih memungkinkan. Anggaran yang tersedia pada setiap pos/pasal merupakan batas tertinggi pengeluaran, oleh karenanya tidak dibenarkan melaksanakan kegiatan /proyek melampaui batas kredit anggaran yang telah ditetapkan. Di samping itu harus pula dihindari kemungkinan terjadinya duplikasi anggaran baik antar unit kerja, antara belanja rutin dan belanja pembangunan serta harus diupayakan terjadinya integrasi kedua 
jenis belanja tersebut dalam satu indikator kinerja. Pengalokasian anggaran harus didasarkan atas skala prioritas yang telah ditetapkan, terutama untuk program yang ditujukan pada upaya peningkatan pelayanan masyarakat. Dengan demikian akan dapat dihindari pengalokasian anggaran pada proyek-proyek yang tidak efisien.

\section{Transparansi dan Akuntabilitas Anggaran}

Transparansi dan akuntabilitas dalam penyusunan anggaran, penetapan anggaran, perubahan anggaran dan perhitungan anggaran merupakan wujud pertanggungjawaban pemerintah daerah kepada masyarakat. Sejalan dengan Code of Good Practices On Fiscal Transparancy yang diperkenalkan oleh IMF, maka dalam proses pengembangan wacana publik di daerah sebagai salah satu instrumen kontrol pengelolaan anggaran daerah perlu diberikan keleluasaan masyarakat untuk mengakses informasi tentang kinerja dan akuntabilitas anggaran. Oleh karena itu, anggaran daerah harus mampu memberikan informasi yang lengkap, akurat dan tepat waktu untuk kepentingan masyarakat, pemerintah daerah, pemerintah pusat dalam format yang akomodatif dalam kaitannya dengan pengawasan dan pengendalian anggaran daerah. Sejalan dengan hal tersebut, maka perencanaan, pelaksanaan dan pelaporan proyek dan kegiatan harus dilaksanakan secara terbuka dan dapat dipertanggungjawabkan secara teknis maupun ekonomis kepada pihak legislatif, masyarakat maupun pihak-pihak independen lain yang memerlukan

\section{Efektivitas Keuangan Daerah}

Efektivitas pengelolaan anggaran daerah dapat dihitung dengan menggunakan rasio perbandingan antara realisasi pendapatan asli daerah dengan target yang ditetapkan dalam APBD. Rumusan rasio efektivitas pengelolaan anggaran daerah adalah sebagai berikut (Mahmudi, 2007: 129):

$$
\text { Efektivitas }=\frac{\text { Realisasi Penerimaan PAD }}{\text { Target Penerimaan PAD }} \times 100 \%
$$

Rasio efektivitas menggambarkan kemampuan pemerintah daerah dalam merealisasikan PAD yang direncanakan dibandingkan target yang ditetapkan. Kriteria rasio efektivitas keuangan daerah dapat mengacu pada tabel 1.6 pada pembahasan latar belakang sebelumnya.

Guna memperoleh ukuran yang lebih baik, rasio efektivitas tersebut perlu dilengkapi dengan rasio efisiensi yang dicapai pemerintah daerah.

\section{Efisiensi Keuangan Daerah}

Efisiensi pengelolaan anggaran daerah adalah rasio yang menunjukkan seberapa besar efisiensi dari suatu pelaksanaan kegiatan/proyek dengan melakukan perbandingan antara output dan input. Rumusan efisiensi yang akan 
dibahas adalah rasio dari realisasi pengeluaran (belanja) daerah dengan total pendapatan daerah (Widodo, 1990: 78).

$$
\text { Efisiensi }=\frac{\text { Total Realisasi Belanja (Pengeluaran) }}{\text { Total Realisasi Pendapatan }} \times 100 \%
$$

\section{Penelitian Terdahulu}

Sumengge (2013) melakukan penelitian yang menganalisis efektifitas dan efisiensi pelaksanaan anggaran belanja BAPPEDA Kabupaten Minahasa Selatan. Analisis data yang digunakan analisis deskriptif. Hasil yang didapat adalah bahwa tingkat dan kriteria efektifitas pelaksanaan anggaran belanja BAPPEDA Minahasa Selatan tahun 2008 - 2012 sangat bervariasi. Tingkat efektifitas tertinggi terjadi pada 2010 dan yang terendah terjadi pada 2011. Pelaksanaan anggaran belanja tahun 2008, 2009, 2010 dan 2012 dikatakan efektif, tetapi pada tahun 2011 tingkat efektifitasnya masih kurang karena realisasi anggaran belanja memiliki perbedaan yang jauh dengan target anggaran belanja. Perbedaan ini terjadi karena ada beberapa kegiatan yang dianggarkan, tapi tidak dilaksanakan. Tetapi untuk kegiatan lain yang telah dianggarkan sudah efektif. BAPPEDA Minahasa Selatan menilai ketika kegiatan yang diprogramkan sudah terealisasi dan sesuai dengan yang diharapkan, maka kegiatan tersebut dikatakan efektif. Pelaksanaan anggaran Belanja BAPPEDA Tahun 2008-2012, secara keseluruhan sudah diolah secara efisien. Pelaksanaan anggaran belanja tahun 2008 sampai 2011, dikategorikan sangat efisien hanya tahun 2012 dikategorikan efisien.

Rondonuwu, et al (2015) melakukan penelitian yang menganalisis apakah pendapatan dan belanja daerah di Dinas Pendapatan Daerah Kabupaten Minahasa telah dilaksanakan secara efisien dan efektif. Metode analisis yang digunakan adalah analisis deskriptif. Hasil penelitian berdasarkan Pedoman Penilaian dan Kinerja Keuangan pada Dinas Pendapatan Daerah Kabupaten Minahasa secara keseluruhan, rata-rata tingkat efektivitas pengelolaan keuangan daerah pada Dinas Pendapatan Daerah Kabupaten Minahasa selama tahun anggaran 2010 sampai dengan tahun 2014 dinyatakan sangat efektif. Hal ini menunjukan kinerja pemerintah dalam merealisasikan pendapatan asli daerah berdasarkan potensi riil daerah dalam tahun anggaran 2010 sampai 2014 sudah sangat baik. Sedangkan secara keseluruhan, rata-rata tingkat efisiensi pengelolaan keuangan pada Dinas Pendapatan Daerah Kabupaten Minahasa selama tahun anggaran 2010 sampai dengan tahun 2014 dinyatakan kurang efisien dikarenakan pengeluaran daerah yang masih tinggi jika dibandingkan dengan total penerimaan daerah.

Ani dan Dwirandra (2013) meneliti tentang pengaruh kinerja keuangan daerah pada pertumbuhan ekonomi, pengangguran dan kemiskinan. Penelitian ini menggunakan sampel 8 kabupaten dan 1 kota pada Provinsi Bali dengan objek penelitian yaitu kinerja keuangan, pertumbuhan ekonomi, pengangguran dan kemiskinan tahun 2007-2011. Hasil penelitian menunjukkan bahwa kinerja keuangan yang terdiri dari rasio kemandirian menunjukan bahwa berpengaruh positif secara signifikan terhadap pertumbuhan ekonomi, sedangkan rasio 
efektivitas, rasio efisiensi, dan pertumbuhan pendapatan tidak berpengaruh signifikan terhadap pertumbuhan ekonomi. Selanjutnya antara kinerja keuangan terhadap pengangguran, menunjukkan bahwa kinerja keuangan berupa rasio kemandirian, rasio efektivitas, rasio efisiensi, dan pertumbuhan pendapatan tidak berpengaruh signifikan terhadap pengangguran, sedangkan antara kinerja keuangan terhadap kemiskinan menunjukkan bahwa rasio kemandirian berpengaruh positif secara signifikan terhadap kemiskinan, dan rasio efektivitas, rasio efisiensi, serta pertumbuhan pendapatan tidak berpengaruh signifikan terhadap kemiskinan.

Bisma dan Susanto (2010) menulis kajian tentang Evaluasi Kinerja Keuangan Daerah Pemerintah Provinsi Nusa Tenggara Barat Tahun Anggaran 2003-2007. Teknik analisis yang digunakan adalah perhitungan terhadap rasio kinerja keuangan daerah yaitu yang meliputi: tingkat kemandirian keuangan, tingkat ketergantungan keuangan, derajat desentralisasi fiskal, efektivitas dan efisiensi. Hasil yang didapat adalah sebagai berikut: (1) Tingkat ketergantungan keuangan Provinsi NTB sangat tinggi terhadap pemerintah pusat sehingga tingkat kemandirian keuangan daerahnya rendah. Sementara, derajat desentralisas fiskalnya juga rendah akibat tingginya ketergantungan dengan pemerintah pusat. Efektivitas keuangan daerah Provinsi NTB berada pada tingkat yang efektif namun efisiensi keuangan daerahnya berada pada tingkat yang tidak efisien.(2) Walaupun pertumbuhan PAD tinggi, namun kontribusi PAD terhadap pendapatan daerah masih rendah. (3) Kemampuan keuangan daerah Provinsi NTB sangat bergantung dengan subsidi dari pusat yaitu melalui dana perimbangan.

Diana (2008: 1-73) melakukan penelitian tentang analisis kinerja laporan keuangan pemerintah Provinsi se-Sumatera Bagian Selatan. Indikator kinerja laporan keuangan yang digunakan adalah efektivitas, efisiensi, ativitas, kemandirian dan pertumbuhan APBD. Hasil yang didapat memberikan bukti empiris bahwa Provinsi Sumatera Selatan memiliki peringkat terbaik atas evaluasi APBD yang dilakukan, sedangkan Provinsi Bengkulu berada pada peringkat terendah atas evaluasi laporan keuangan yang dilakukan. Dalam penelitian itu juga dilakukan uji beda Kolmogorov Smirnov yang kemudian menunjukkan bahwa terdapat perbedaan yang nyata dalam evaluasi pelaksanaan laporan keuangan. Beda penelitian Diana dengan penelitian penulis adalah penelitian Diana hanya menganalisis kinerja keuangan saja tanpa melihat pengaruhnya terhadap pertumbuhan ekonomi

\section{Kerangka Pemikiran} berikut ini.

Kerangka pemikiran dalam penelitian ini disusun seperti dalam bagan

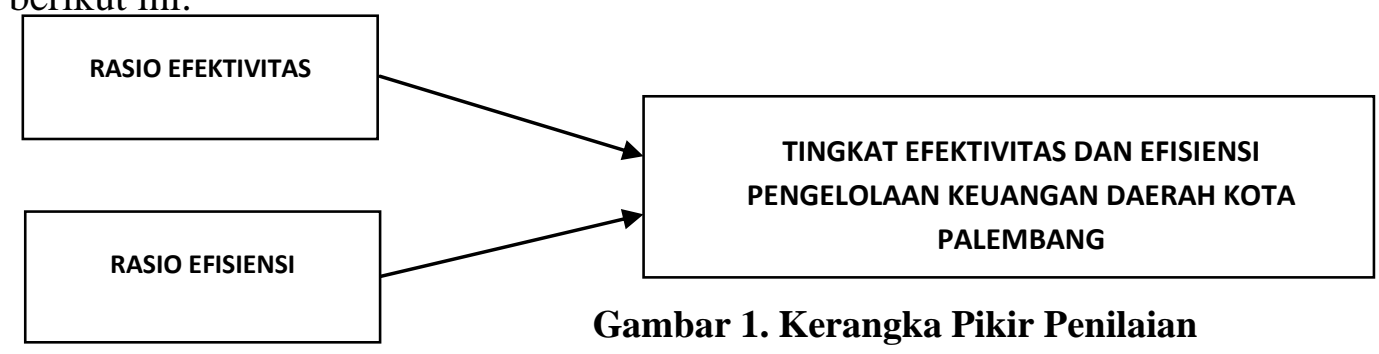


Bagan di atas menggambarkan bahwa penelitian ini menganalisis tingkat efektivitas dan efisiensi pengelolaan keuangan daerah di Kota Palembang melalui perhitungan terhadap rasio efektivitas dan efisiensi keuangan daerah.

\section{METODE PENELITIAN}

\section{Ruang Lingkup Penelitian}

Ruang lingkup penelitian ini dibatas pada pembahasan terhadap efektivitas dan efisiensi pengelolaan keuangan daerah Kota Palembang.

\section{Jenis dan Sumber Data}

Data yang digunakan dalam penelitian ini adalah data sekunder. Data tersebut adalah data Laporan Keuangan Pemerintah Kota Palembang yang berupa data anggaran dan realisasi APBD serta pertumbuhan ekonomi Kota Palembang. Periode data yang diambil adalah selama 10 (sepuluh) tahun yaitu 2003 - 2013.

\section{Metode Pengumpulan data}

Dalam penelitian ini data dikumpulkam adalah data sekunder yang berasal dari data instansi-instansi yang terkait yaitu misalnya Dinas Pendapatan Daerah, Biro Keuangan Pemerintah Kota Palembang serta Badan Pusat Statistik (BPS) Sumsel dan Kota Palembang.

\section{Teknik Analisis Data}

Teknik analisis yang digunakan yaitu dengan cara menghitung Rasio Efektivitas Keuangan Daerah dan Rasio Efisiensi Keuangan Daerahseperti yang telah dikemukakan pada bagian sebelumnya.

Kriteria Rasio Efektivitas Keuangan Daerah diambil dari kriteria penilaian yang ditentukan oleh Departemen Dalam Negeri melalui Kepmendagri No. 690.900.327 tahun 1996 tentang Pedoman Penilaian Kinerja Keuangan dengan ketentuan sebagai berikut:

Tabel 1.

Kriteria Kinerja Efektivitas Keuangan

\begin{tabular}{|c|c|c|}
\hline No & $\begin{array}{c}\text { Persentase Kinerja } \\
\text { Keuangan }\end{array}$ & Kriteria \\
\hline 1 & $100 \%$ keatas & Sangat efektif \\
2 & $90-100 \%$ & Efektif \\
3 & $80-90 \%$ & Cukup efektif \\
4 & $60-80 \%$ & Kurang efektif \\
5 & kurang $60 \%$ & Tidak efektif \\
\hline
\end{tabular}

Sumber: Depdagri, Kepmendagri No. 690.900.327 tahun 1996

tentang pedoman penilaian kinerja keuangan, 1997 
Sementara kriteria Rasio Efisiensi Keuangan Daerah juga diambil dari Kepmendagri No. 690.900.327 tahun 1996 tentang Pedoman Penilaian Kinerja Keuangan. Berikut ini tabel 2. yang menggambarkan kriteria Rasio Efisiensi Keuangan Daerah.

Tabel 2.

Kriteria Kinerja Efisiensi Keuangan

\begin{tabular}{|c|c|c|}
\hline No & Persentase Kinerja Keuangan & Kriteria \\
\hline 1 & $100 \%$ ke atas & Tidak efisien \\
2 & $90-100 \%$ & Kurang Efisien \\
3 & $80-90 \%$ & Cukup efisien \\
4 & $60-80 \%$ & Efisien \\
5 & kurang $60 \%$ & Sangat efisien \\
\hline
\end{tabular}

Sumber: Depdagri, Kepmendagri No. 690.900.327 tahun 1996 tentang pedoman penilaian kinerja keuangan, 1997

\section{HASIL DAN PEMBAHASAN}

\section{Efektivitas Keuangan Daerah}

Seperti yang telah dibahas sebelumnya, efektivitas keuangan daerah dihitung dengan menggunakan rasio perbandingan antara realisasi Pendapatan Asli Daerah (PAD) dengan target PAD yang ditetapkan dalam APBD. Rasio ini bertujuan untuk melihat bagaimana kemampuan pemerintah daerah menyusun target anggaran PAD dan merealisasikannya. Semakin besar rasio perbandingan realisasi PAD dibandingkan target anggarannya maka akan semakin efektif pengelolaan keuangan daerah. Berikut ini Tabel 3 yang menggambarkan perkembangan Efektivitas Keuangan Daerah Kota Palembang pada periode 20032013.

Tabel 3.

Efektivitas Keuangan Daerah Kota Palembang Tahun 2003-2013

\begin{tabular}{|l|l|l|}
\hline Tahun & Efektivitas & Kriteria \\
\hline 2003 & 95,0 & Efektif \\
\hline 2004 & 90,0 & Efektif \\
\hline 2005 & 97,0 & Efektif \\
\hline 2006 & 89,0 & Cukup Efektif \\
\hline 2007 & 95,0 & Efektif \\
\hline 2008 & 80,8 & Cukup Efektif \\
\hline 2009 & 75,9 & Kurang Efektif \\
\hline 2010 & 102,1 & Sangat Efektif \\
\hline 2011 & 100,4 & Sangat Efektif \\
\hline 2012 & 113,8 & Sangat Efektif \\
\hline 2013 & 100,7 & Sangat Efektif \\
\hline
\end{tabular}

Sumber: Data Olahan, 2014 
Berdasarkan data pada Tabel 3 di atas terlihat bahwa rasio efektivitas keuangan daerah mengalami fluktuasi setiap tahunnya. Namun secara keseluruhan efektivitas keuangan daerah Kota Palembang rata-rata berada pada kriteria efektif dan sangat efektif.

Rasio efektivitas keuangan daerah memberikan gambaran bagaimana kinerja keuangan pemerintah daerah dalam merealisasikan PAD dari nilai target anggarannya. Rasio ini merupakan besar persentase PAD yang terealisasi dibandingkan target anggarannya. Dengan demikian, rasio ini memberikan informasi bagaimana sejauh mana upaya-upaya pemerintah daerah setempat memaksimalkan potensi PAD agar dapat terserap secara optimal misalnya melalui pajak dan retribusi daerah.

Dari tabel di atas terlihat bahwa dari tahun 2003-2007 rasio efektivitas keuangan daerah Kota Palembang rata-rata mencapai nilai 93,2. Angka ini menunjukkan bahwa rata-rata pencapaian realisasi PAD selama periode tersebut adalah sebesar 93,2 persen dari target anggarannya. Namun pada tahun 2008 turun menjadi 80,8 dan titik paling rendah yaitu pada tahun 2009 dengan nilai 75,9. Penurunan ini disebabkan adanya dampak kelesuan ekonomi akibat krisis ekonomi yang melanda AS dan Eropa pada kurun waktu akhir 2008 hingga 2009. Krisis ekonomi ini sangat mempengaruhi ekspor beberapa komoditi Provinsi Sumatera Selatan pada umumnya dan Kota Palembang pada khususnya sehingga menurunkan realisasi penerimaan pajak pada periode tersebut. Rasio efektivitas keuangan daerah Kota Palembang kembali meningkat setelah tahun 2009 hingga 2013 dengan rata-rata nilai sebesar 104,2 pertahun. Angka tersebut berarti realisasi PAD terhadap target angggarannya sudah mencapai rata-rata 104,2 persen selama 2010-2013.

\section{Efisiensi Keuangan Daerah}

Pada bab sebelumnya dikatakan bahwa efisiensi keuangan daerah merupakan rasio yang menghitung persentase perbandingan realisasi belanja daerah terhadap realisasi total pendapatan daerah. Tabel 4 berikut ini menggambarkan perkembangan tingkat Efisiensi Keuangan Daerah Kota Palembang pada periode tahun 2003-2013.

Tabel 4.

Perkembangan Efisiensi Keuangan Daerah Kota Palembang 2003-1013

\begin{tabular}{|l|l|l|}
\hline Tahun & Efisiensi & Kriteria \\
\hline 2003 & 95,7 & Kurang Efisien \\
\hline 2004 & 95,7 & Kurang Efisien \\
\hline 2005 & 81,6 & Cukup Efisien \\
\hline 2006 & 95,1 & Kurang Efisien \\
\hline 2007 & 96,1 & Kurang Efisien \\
\hline 2008 & 105,9 & Tidak Efisien \\
\hline 2009 & 101,5 & Tidak Efisien \\
\hline
\end{tabular}




\begin{tabular}{|l|l|l|}
\hline 2010 & 80,6 & Cukup Efisien \\
\hline 2011 & 98,6 & Kurang Efisien \\
\hline 2012 & 94,3 & Kurang Efisien \\
\hline 2013 & 100,6 & Tidak Efisien \\
\hline
\end{tabular}

Sumber: Data Olahan, 2014

Tabel 4 menggambarkan bahwa tingkat efisiensi keuangan daerah Kota Palembang selama periode 2003-2013 rata-rata berada pada tingkat kurang efisien dan tidak efisien. Hanya pada tahun 2005 dan 2010 efisiensi pengelolaan keuangan daerah Kota Palembang berada pada tingkat cukup efisien dengan nilai rasio berturut-turut adalah 81,6 dan 80,6.

Semakin bersar nilai rasio efisiensi keuangan maka semakin tidak efisien pengelolaan keuangan daerah Kota Palembang. Hal ini menyangkut perbandingan output dan input pelaksanaan kegiatan/proyek pembangunan dan pelayanan publik. Semakin besar belanja artinya semakin besar input yang digunakan sementara kualitas output yang dihasilkan hanya dapat diukur dengan ukuran seberapa besar efek kegiatan/proyek tersebut mampu meningkatkan pertumbuhan ekonomi daerah dan kesejahteraan masyarakat. Input yang terlampau besar dalam proses pelaksanaan suatu kegiatan tidak sesuai dengan prinsip efisiensi dalam ekonomi. Suatu kegiatan dikatakan efisien apabila mencapai hasil yang baik dengan pengorbanan (biaya) biaya yang sedikit.

Rasio Efisiensi Keuangan Daerah Kota Palembang selama periode 20032013 mencapai rata-rata 95,1 yang artinya rata-rata nilai realisasi belanja mencapai 95,1 persen dari nilai realisasi pendapatan pertahun. Pada tahun 2008, 2009, dan 2013 Rasio Efisiensi Keuangan Daerah mencapai nilai yang melebihi 100 persen dari nilai realisasi pendapatan daerah yaitu sebesar 105,9, 101,5, dan 100,6. Ini menandakan belanja daerah telah melebihi anggaran yang tersedia sehingga pengeluaran belanja tersebut dibiayai dengan pinjaman/hutang.

\section{KESIMPULAN}

Berdasarkan hasil analisis yang telah dipaparkan sebelumnya maka didapati kesimpulan sebagai berikut:

1. Secara keseluruhan, rata-rata nilai rasio efektivitas keuangan daerah Kota Palembang periode tahun 2003-2013 mencapai tingkat yang efektif. Hal ini berarti pemerintah daerah Kota Palembang telah berhasil dalam merealisasikan Pendapatan Asli Daerah (PAD) dari target yang diperkirakan sebelumnya sehingga potensi PAD yang ada dapat dimaksimalkan oleh pemerintah daerah untuk menunjang pembangunan di Kota Palembang.

2. Tingkat efisiensi keuangan daerah Kota Palembang selama periode 20032013 rata-rata berada pada tingkat kurang efisien dan tidak efisien. Hal ini berarti porsi penggunaan input (belanja) telah lebih dari 90 persen dibandingkan jumlah output (pendapatan). Dalam terminologi ekonomi dan keuangan hal ini merupakan kondisi yang tidak efisien bahkan pada periode tahun 2009, 2009 dan 2013 rasio efisiensi telah melebihi dari angka 100 
persen yang menandakan belanja daerah telah melebihi anggaran yang tersedia sehingga pengeluaran belanja tersebut dibiayai dengan pinjaman/hutang.

\section{DAFTAR PUSTAKA}

Ani, Ni Luh Nana Putri \& Dwirandra, A.A.N.B. 2013. Pengaruh Kinerja Keuangan Daerah Pada Pertumbuhan Ekonomi, Pengangguran dan Kemiskinan Kabupaten dan Kota. E-Journal Akuntansi Universitas Udayana 6.3 (2014): 481-497

(http://ojs.unud.ac.id/index.php/Akuntansi/article/viewFile/8341/6218, diakses 10 Juli 2014)

Badan Pusat Statistik. 2013. Palembang Dalam Angka. BPS Provinsi Sumsel. Palembang

Bisma, I Dewa Gde \& Susanto, Hery. 2010. Evaluasi Kinerja Keuangan Daerah Pemerintah Provinsi Nusa Tenggara Barat Tahun Anggaran 2003 - 2007. GaneÇ Swara Edisi Khusus Vol. 4 No.3 Desember. (http://unmasmataram.ac.id/wp/wp-content/uploads/12.-I-Dewa-GdeBisma.pdf, diakses 2 April 2016)

Departemen Keuangan RI. 2009. Buku 2: Pedoman Penganggaran Berbasis Kinerja $(P B K)$.

Jakarta.(http://www.anggaran.depkeu.go.id/Content/buku_2.pdf , diakses 8 September 2015)

Devas, et al. 1989. Keuangan Pemerintah Daerah di Indonesia (terjemahan Masri Maris). UI-Press. Jakarta.

Diana, Rita. 2008. Analisis Kinerja Atas Laporan Keuangan Pemerintah Provinsi Se-Sumatera Bagian Selatan. Tesis Program Pasca Sarjana Universitas Sriwijaya. Palembang (tidak dipublikasikan).

Halim, Abdul. 2007. Bunga Rampai: Manajemen Keuangan Daerah. Edisi Pertama. UPP AMP YKPN. Yogyakarta.

Mahmudi. 2007. Analisis Laporan Keuangan Pemerintah Daerah: Panduan Baig Eksekutif, DPRD dan Masyarakat dalam Pengambilan Keputusan Ekonomi, Sosial dan Politik. STIM YKPN. Yogyakarta

Mardiasmo. 1999. Otonomi Daerah Yang Berorientasi Pada Kepentingan Publik. Dibawakan pada National Seminar Promoting Good Governance. PAU-SE UGM. Yogyakarta. 
PAU-SE UGM. 2000. Pedoman Penyusunan dan Pelaksanaan APBD. UGM. Jakarta.

Pemerintah RI. 2005. Peraturan Pemerintah No. 24 Tahun 2005 tentang Standar Akuntansi Pemerintahan. Pustaka Pergaulan. Jakarta.

Pemerintah RI. 2006. Peraturan Menteri Dalam Negeri No. 13 Tahun 2006 tentang Pedoman Pengelolaan Keuangan Daerah. CV. Eko Jaya. Jakarta.

Rondonuwu, R.H., et al. 2015. Analisis Efisiensi Dan Efektivitas Pengelolaan Keuangan Daerah Pada Dinas Pendapatan Daerah Kabupaten Minahasa. Jurnal EMBA Vol.3 No.4 Desember 2015 Hal. 23-32. (http://download.portalgaruda.org/article.php?article=377944\&val=1025\& $\underline{\text { title}=A N A L I S I S \% 20 E F I S I E N S I \% 20 D A N \% 20 E F E K T I V I T A S \% 20 P E N G ~}$ ELOLAAN\%20KEUANGAN\%20DAERAH\%20PADA\%20DINAS\%20P ENDAPATAN\%20DAERAH\%20KABUPATEN\%20MINAHASA diakses 9 Februari 2016)

Sumenge, Ariel Sharon. 2013. Analisis Efektifitas dan Efisiensi Pelaksanaan Anggaran Belanja Badan Perencanaan Pembangunan Daerah (Bappeda) Minahasa Selatan. Jurnal EMBAVol.1 No.3 September 2013, Hal. 74-81. (https://www.academia.edu/6072178/ANALISIS_EFEKTIFITAS_DAN_E FISIENSI_PELAKSANAAN_ANGGARAN_BELANJA_BADAN_PERE NCANAAN_PEMBANGUNAN_DAERAH_BAPPEDA_MINAHASA_S ELATAN_Oleh_Ariel_Sharon_Sumenge, diakses 8 September 2015)

Widodo, Hg. Tryanto. 1990. Indikator Ekonomi. Cetakan ke-10. Kanisisus.

Yuwono, et al. 2005. Penganggaran Sektor Publik. Bayu ME. Malang 